\title{
MITHRAX (MITHRAX) PLEURACANTHUS STIMPSON, 1871, A NEW DECAPOD FOR THE BRAZILIAN FAUNA
}

\section{LILIANA FORNERIS JOSE CARLOS DE FREITAS}

\section{ABSTRACT}

Mithrax (M.) pleuracanthus Stimpson, 1871, was collected in the upper sublittoral on both sides of the São Sebastião Channel $\left(23^{\circ} 48^{\prime} S, 45^{\circ} 23^{\prime} \mathrm{W}\right)$. The geographical distribution, ecological notes and main morphological characters of the species are given.

The genus Mithrax, containing thirty-one determined species, has an amphi-American distribution (Ekman, 1953:32, fig. 7). For the Western Atlantic coast twenty species of Mithrax are mentioned, and up to date ten species have been found on the Brazilian coast, seven belonging to the subgenus Mithrax and three to the subgenus Mithraculus. The greatest percentage of species occurs on the northeastern coast (Coelho, 1971; Coelho \& Ramos, 1972), the area most studied.

Only two species are mentioned occurring south of Rio de Janeiro: Mithrax (Mithrax) hispidus (Herbst, 1790) (Ubatuba and São Sebastião) (Luederwaldt, 1919:432) and Mithrax (Mithraculus) coryphe (Herbst, 1785) (Vitória Island, São Paulo) (Rathbun, 1925:428).

Observations on the species Mithrax (Mithrax) pleuracanthus Stimpson, 1871, collected in São Sebastião were made during a study of chemical defense behaviour of brachyuran crustaceans (Freitas, 1980). This was the first occurrence of the species in Brazil.

Six adult males and juvenile females were collected at a depth of between 4 and $12 \mathrm{~m}$ by Scuba diving. The large make measured $45 \mathrm{~mm}$ length and $61 \mathrm{~mm}$ width; the juvenile female, $20 \mathrm{~mm}$ length and $25 \mathrm{~mm}$ width.

The specimens studied agree with the description of $M$. pleuracanthus given by Rathbun (1925:411). The main characteristics of the species (Fig. 1) are the four lateral carapace protuberances, the last being spiniform and the others tuberculated.

The transverse row of five tubercules in the gastric region mentioned by Williams $(1965: 254)$ in his key to species of the Carolinas, to separate $M$. pleuracanthus from $M$. hispidus, is conspicuous in juvenile specimens of both species. In the adult stage, this row is not easily distinguished.

The first pleopod in the male has the usual shape, but the truncated apex (Fig. 2) does not conform to the figure given by Williams (1965:625, fig. $275 \mathrm{D})$. However, this difference may be due to the age of the specimens (Garth, 1958:12).

Distribution - Beaufort, North Carolina to Gulf of Mexico and the Caribbean Sea: Bahamas, Curaçao (Garth, 1978:311). São Sebastião Island and the littoral of São Sebastião, State of São Paulo, Brazil.

Ecological notes - The species occurs in shallow waters to a depth of about $50 \mathrm{~m}$ (Garth, 1978).

Temperature: $11.7^{\circ} \mathrm{C}$ to $23.5^{\circ} \mathrm{C}$. Bottom: on seagrass, sand, rocks, coral, gravel, and rarely in mud (Rathbun, 1925:412-417); on coral reefs formed by the species Oculina arbuscula Verrill (Goy et al., 1981); inside sponges (Pearse, 1934 in Williams).

Ovigerous females have been reported from North Carolina in April, from Florida in December, January, February, and August; from Tortugas in De-

Departamento de Zoologia, Instituto de Biociências, Universidade de Săo Paulo, São Paulo, SP. 


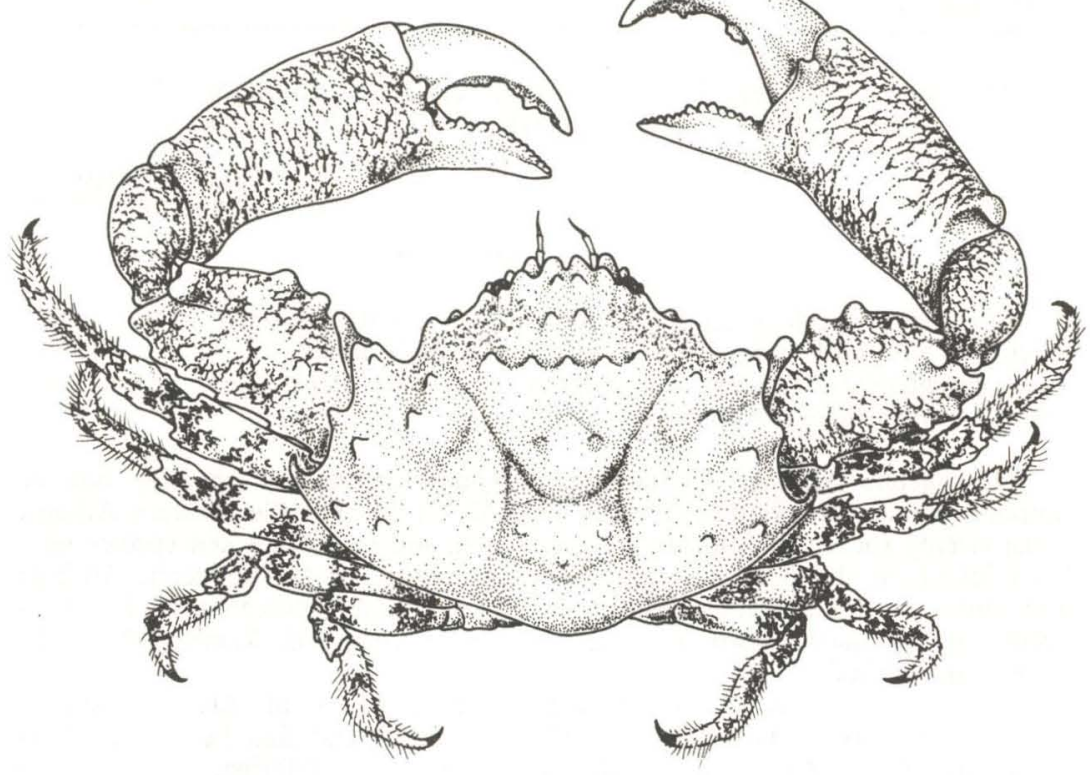

Fig. 1 - Mithrax (Mithrax) pleuracanthus Stimpson. Male in dorsal view. Size: $4.2 \mathrm{~cm} \times 5.6 \mathrm{~cm}$.

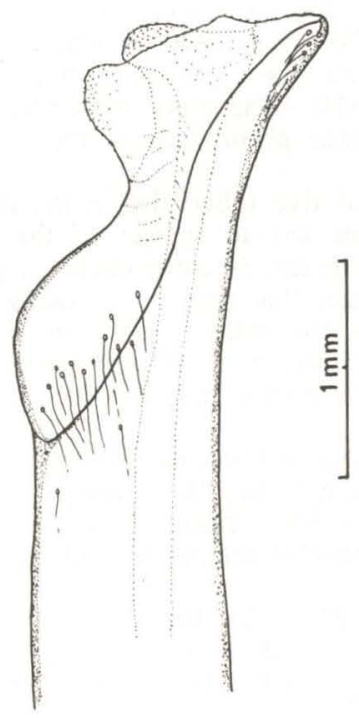

Fig. 2 - Mithrax (Mithrax) pleuracanthus Stimpson. Apex of right first pleopod of a $4.2 \mathrm{~cm}$ male. 
cember; from St. Thomas area in July, and from Venezuela in September (Rathbun; Williams).

The dorsal surface of the carapace, the antero-lateral margins of the same, and the pereiopods of some specimens were covered by serpulids, oyster, barnacles, and bryozoans.

Mithrax pleuracanthus lives associated with $M$. (Mithraculus) forceps (A. Milne Edwards, 1875) North Carolina (Williams, 1965) and with M. hispidus in São Sebastião.

It was found in the upper sublittoral under stones embedded in sand. The crabs grasp the underside of the stones with the pointed dactylus, an adaptation to exposed environments. This behaviour was also observed in $M$. hispidus, which lies hidden under rocks in shallow water.

\section{REFERENCES}

Coelho, P. A., 1971. Nota prévia sobre Majidae do Norte e Nordeste do Brasil. Arqos Mus. nac. Rio de J. 54: 137-143.

Coelho, P. A. \& M. de A. Ramos, 1972. A constituição e a distribuição da fauna de decápodos do litoral leste da América do Sul entre as latitudes de $5^{\circ} \mathrm{N}$ e $39^{\circ} \mathrm{S}$. Trabs oceanogr. Univ. Recife 13: 133-236.

Ekman, S., 1953. Zoogeography of the sea, 417 pp. Sidgwick and Jackson Ltd, London.

Freitas, J. C. de, 1980. Evidências de um possível comportamento de defesa química em crustáceos decápodes braquiuros. Bolm Fisiol. anim. Univ. $S$ Paulo 4: 153-161.

Garth, J. S., 1958. Brachyura of the Pacific coast of America. Oxyrhyncha. Allan Hancock Pacif. Exp. 21(1): 1-499.

Garth, J. S., 1978. Marine biological investigations in the Bahamas. 19. Crustacea Brachyura. Sarsia 63(4): 317-333.

Goy, J. W., C. G. Bookhout \& J. D. Costlow, Jr., 1981. Larval development of the spider crab Mithrax pleuracanthus Stimpson in the laboratory (Decapoda: Brachyura: Majidae). J. Crust. Biol. 1(1): 51-62.

Rathbun, M. J., 1925. The spider crabs of America. Bull. U. S. natn. Mus. 152: $1-609$.

Williams, A. B., 1965. Marine decapod crustaceans of the Carolinas. U. S. Fish. Bull. 65: 1+298. 